УДК 621.774 .35

\author{
С.Р. Рахманов ${ }^{1}$, С.В. Білодіденко ${ }^{2}$, В.І. Гануш ${ }^{2}$, І.П. Хацкелян ${ }^{3}$, В.В. Поворотний ${ }^{1}$ \\ ${ }^{1}$ НВП «Восток Плюс» \\ ${ }^{2}$ Національна металургійна академія України \\ ${ }^{3}$ Інтерпайп Україна
}

\title{
ЗАБЕЗПЕЧЕННЯ НАДІЙНОСТІ СТАНИНИ РОБОЧОЇ КЛІТІ ПРОШИВНОГО СТАНУ ТПА 350 ПІСЛЯ ЇЇ ДОВГОТРИВАЛОЇ ЕКСПЛУАТАЦІї
}

\begin{abstract}
Наведено результати досліджень 3D моделі станин прошивного стану ТПА 350. Визначено напружено-деформований стан робочої кліті прошивного стану ТПА 350. Встановлено, що в станині робочої кліті прошивного стану виникають максимальні напруження в зонах виявлених раніше тріщин, місця концентрації максимальних напружень «мігрують» при зміні умов закріплення станіни. Виявлено, що небезпеку представляють дефекти (тріщини), які з'являються в напружених зонах станини робочої кліті. Виявлено, що початкові розміри дефектів малі для надійного діагностування, але їх критичні розміри достатньо великі, щоб їх не виявити при обстеженнях. Встановлено, що безпека станини прошивного стану при більш жорстких умовах експлуатації, які фактично спостерігаються у реальності, була вичерпана після 75 років експлуатації. Розрахунки показують, що в даний момент станина прошивного стану працює в зоні повного ризику, що супроводжується утворенням тріщин. Період живучості сферичного дефекту становить близько 5 років, після цього дефект трансформується в тріщину з погано визначною геометрією й розвивається по закономірностях, що вимагають окремого вивчення. Показано, що найбільш ефективно в цьому плані здійснювати іiі контроль неруйнуючими діагностичними методами. Для продовження експлуатації станини прошивного стану пропонується: надійно закріпити верхню кришку станини прошивного стану гвинтовим механізмом фіксації. Дослідженнями напружено-деформованого стану встановлено, що зазори в місці з'єднання кришки й станини робочої кліті сприяють росту локальних напружень, наслідки появи яких аналізувалися в даній роботі. Запропоновано максимально знизити (виключити) кількість труб, що виготовляються, із сплавів, що важко деформуються, робити діагностування кліті й регулярно перевіряти розміри тріщин.
\end{abstract}

DOI: $10.34185 / 0543-5749.2020-3-3-17$

\section{Вступ}

Подальший розвиток процесів виробництва гарячекатаних труб ставить завдання підвищення якості продукції, що випускається, а також пошуку нових підходів до модернізації і забезпечення довговічності робочих елементів прошивних станів трубопрокатних агрегатів (ТПА). Вирішення даного завдання нерозривно пов'язане 3 удосконалюванням існуючого обладнання, а також зі створенням принципово нових деталей і вузлів робочих клітей прошивних станів.
Численні результати аналізу руйнувань базових деталей прошивних станів ТПА 350 показали, що ці руйнування пов'язані зі старінням усього обсягу матеріалу деталі в процесі тривалої експлуатації (більше 80 років). Причини руйнування у вигляді локальних зон, конструктивних i технологічних концентраторів напружень, існували із самого початку експлуатації і могли бути "закладені" у конструкцію прошивних станів ТПА 350, як заводом-виготовлювачем на стадіях проектування, виготовлення і монтажу, так i 
в процесі експлуатації. Зі збільшенням строків експлуатації інтенсифікуються процеси накопичення втомних пошкоджень, виникнення і росту втомних тріщин, що призводить до руйнування станин прошивних станів ТПА 350.

\section{Постановка задачі}

Станини прошивних станів ТПА (рис. 1, а), які є базовими конструкціями, проектували за критеріями забезпечення міцності. Питання про їхню довговічність не виникало, хоча саме строк служби станини, багато в чому, визначає дату виведення з експлуатації всього агрегату. Конструктивно станина прошивного стану складається $з$ вертикально розташованих стійок, відлитих разом з основою [1].

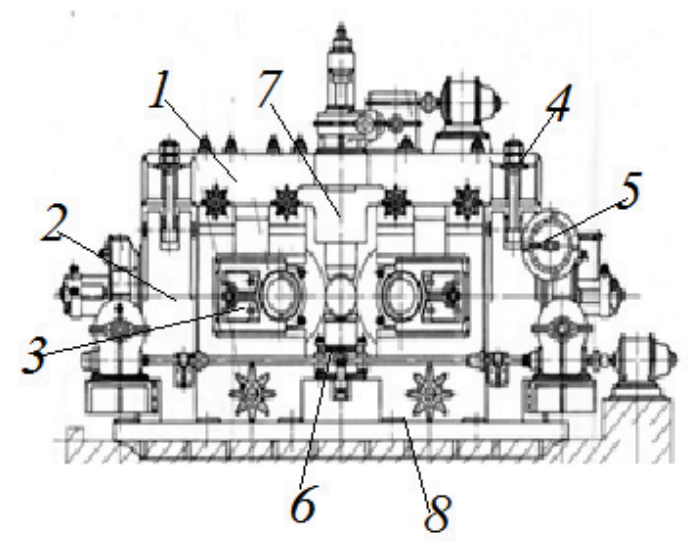

a)
Розрахований запас міцності не завжди забезпечує безаварійну надійну роботу станини прошивного стану. У ряді випадків вони руйнуються, тому що діючі змінні напруження виявляються вище границі витривалості. Зростання напруженості станини може відбуватися, як через велику концентрацію напружень, не оцінену належним чином при проектуванні станини, так і у результаті збільшення навантажень, пов'язаних з інтенсифікацією режимів прокатки труб. Об'єктами досліджень напруженодеформованого стану були робочі кліті прошивних станів № 1 і № 2 ТПА 350. На підставі існуючої технічної документації робочої кліті прошивного стану ТПА 350 розроблена іï тривимірна модель (рис. 1, б).

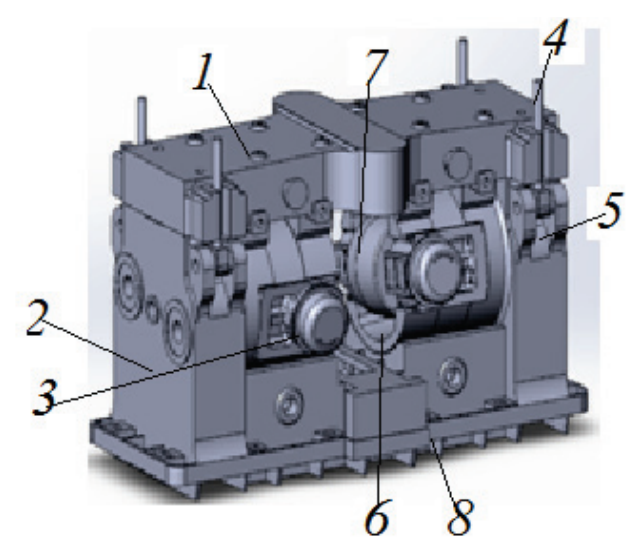

б)

Рис. 1. Робоча кліть (а) і тривимірна модель кліті (б) прошивного стану ТПА 350, розроблена на базі існуючої технічної документації: 1 - кришка; 2 - станина; 3 - барабан 3 валком; 4 - кріплення кришки; 5- механізм встановлення валка; 6 - лінійкоутримувач нижній; 7 - лінійкоутримувач верхній; 8 - основа

\section{Ціль роботи}

Дослідження напружено-деформованого стану станин кліті прошивних станів ТПА 350 ТОВ «ІНТЕРПАЙП НІКО-ТЬЮБ»; комПлексне експертно-технічне обстеження іiі стану при прокатці основного сортаменту; постановка завдання на розробку моделі кліті 3 метою iï застосування для обгрунтування стратегії подальшої експлуатації прошивного стану ТПА 350.

\section{Метод вирішення задачі}

У процесі дослідження в рамках науководослідної роботи проводилися виміри напружень, що виникають у станині прошивних ста- нів 50 при прокаті обраних пакетів труб. Напруження замірялися у найбільш активних зонах станин. Закріплення «розеток» (систем із трьох тензодатчиків) на станині прошивного стану ТПА 350 наведені на рис. 2. Також були виконані виміри зусиль на натискних гвинтах робочої кліті двох прошивних станів ТПА 350. 3 осцилограм сили тиску металу на натискні гвинти прошивного стану № 1 ТПА 350 встановлено, що елементи робочої кліті сприймають значні знакозмінні технологічні навантаження. Відповідні цьому процесові деформації в найбільш навантажених елементах робочої кліті напряму впливають на якість продукції, що випускається. 
Для дослідження напружено-деформованого стану елементів конструкцій кліті використано методу скінчених елементів (MCE) на базі стандартного пакета програмної продукціï Solid Works Simulation [2, 3]. Для цього були створені тривимірні комп'ютерні моделі стани- ни робочої кліті прошивного ТПА 350 у двох варіантах виконання. Схема навантаження станини робочої кліті прошивного стану № 1 ТПА $350 \quad 3$ урахуванням параметрів 3D моделі наведена на рис. 2.

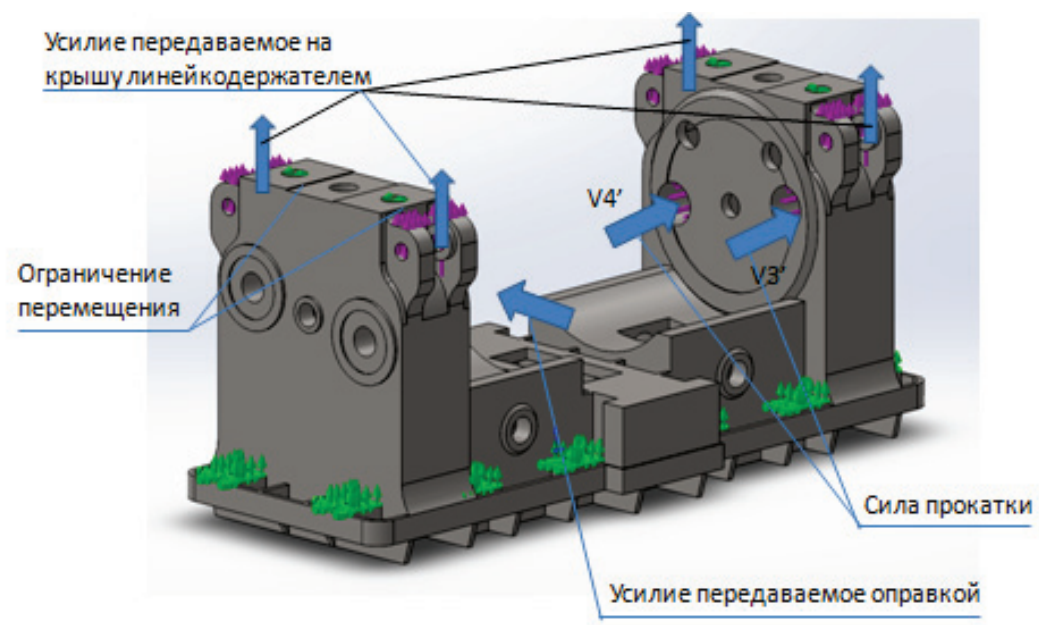

Рис. 2. Схема навантаження станини робочої кліті прошивного стану № 1 ТПА 350

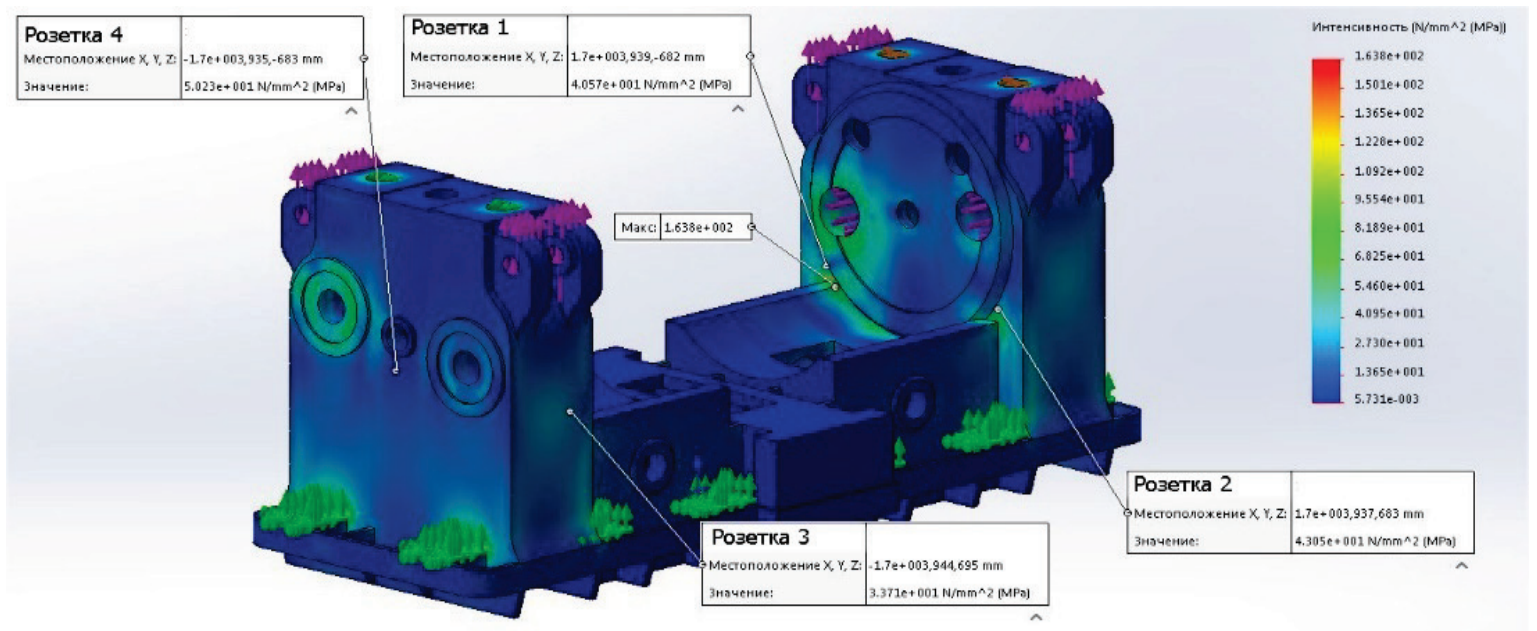

Рис. 3. Поля напружень у конструкції станини прошивного стану № 1 ТПА 350 (номінальний діаметр труби - 323,9 мм, номінальна товщина стінки - 20 мм, діаметр гільзи - 274 мм, товщина стінки труби після прокату - 44 мм, сталь 20)

Поля напружень в станині прошивного стану № 1 ТПА 350 наведені на рис. 3 (номінальний діаметр труби - 323,9 мм, номінальна товщина стінки - 20 мм, діаметр гільзи - 274 мм, товщина стінки труби після прокату - 44 мм, сталь 20). 3 картин напружено-деформованого стану (рис. 3). видно, що в станині робочої кліті прошивного стану № 1 ТПА 350 виникають ви- сокі напруження в зонах, де виникають тріщини.

3 3D моделі напружено-деформованого стану станини прошивного стану № 1 ТПА 350 встановлено, що місця концентрацій максимальних напружень «мігрують» при зміні умов закріплення (фіксації) кришки робочої кліті. Базуючись на характерних картинах напруженодеформованого стану усіх елементів робочої 
кліті прошивного стану ТПА 350 оцінено довговічність самої станини. При несприятливих комбінаціях умов експлуатації і стану обладнання в станині прошивного стану (ПС) виникають напруження $\sigma_{1}=133$ МПа при прошиванні рядових сталей (це $80 \%$ труб, тобто, відносна тривалість дії 1-го рівня блока навантаження $\left.\mathrm{c}_{1}=0,8\right)$ і напруження $2_{2}=149$ МПа при прошиванні сталей, що важко деформуються (20\% труб, $\left.\mathrm{c}_{2}=0,2\right)$.

Станина виконана зі сталі 35Л с межею міцності $\sigma_{\text {в }}=500 \mathrm{MПа} \mathrm{і} \mathrm{експлуатується} \mathrm{близько}$ 80 років. Порівняння результатів напруженодеформованого стану (НДС), отриманих за допомогою методу скінчених елементів і тензоме- тричного методу для ПС № 1 ТПА 350 наведено в таблиці 1.

При дослідженні напружено-деформованого стану станин прошивних клітей трубопрокатних агрегатів були виявлені місця максимальних значень напружень, що виникають в районі кріплення гвинта. Подібна картина спостерігається в автомат стані та станах, що мають рамну конструкцію 3 вибіркою під натискний гвинт і в разі виникнення руйнувань, проводяться заходи, щодо продовження ресурсу станини при мінімальних фінансових витратах $[4,5]$. Однак в порівнянні з реальною картиною руйнувань станин, місця максимальних значень напружень не збігаються з місцями виникнення тріщин.

Таблиця 1. Порівняння результатів НДС, отриманих МСЕ і тензометричного методу для ПС №1 ТПА 350

\begin{tabular}{|c|c|c|c|c|c|c|c|c|c|}
\hline \multirow{3}{*}{$\begin{array}{c}\text { Метод } \\
\text { дослідження }\end{array}$} & \multirow{3}{*}{ 疍 } & \multicolumn{8}{|c|}{ Напряжения в местах крепления датчиков, МПа } \\
\hline & & \multicolumn{4}{|c|}{$\begin{array}{c}\text { Труба 323,9x8 } \\
\text { Гільза 277х24 } \\
\text { V3=416кH, V4=1675кH } \\
\text { V4/V3=4,02 }\end{array}$} & \multicolumn{4}{|c|}{$\begin{array}{c}\text { Труба } 323,9 \times 20 \\
\text { Гільза } 277 \times 44 \\
\text { V3=735кH, V4=1513кН } \\
\text { V4/V3=2,06 }\end{array}$} \\
\hline & & $1 \mathrm{BX}$ & 2вих & 3вих & 4вX & $1 \mathrm{BX}$ & 2вих & Звих & 4вх \\
\hline \multirow{3}{*}{$\begin{array}{c}\text { Тензометричний } \\
\text { метод }\end{array}$} & $\sigma^{I I I}$ & 53,28 & 27,16 & 28,1 & 27,49 & 51,55 & 29,57 & 28,15 & 27,35 \\
\hline & $\sigma_{1}$ & 51,28 & 50,94 & 37,38 & 49,51 & 54,35 & 57,22 & 39,4 & 53,2 \\
\hline & $\sigma_{3}$ & -2 & 23,78 & 9,28 & 22,02 & 2,8 & 27,65 & 11,25 & 25,85 \\
\hline \multirow{4}{*}{ MCE } & $\sigma^{\mathrm{III}}$ & 39,7 & 30,5 & 31 & 47,46 & 40 & 43 & 33 & 50 \\
\hline & $\sigma_{1}$ & 36,7 & 39 & 33,5 & 49,8 & 38 & 43 & 36 & 50 \\
\hline & $\sigma_{3}$ & -3 & 8,5 & 2,5 & 2,34 & -2 & 8 & 2,5 & 4,3 \\
\hline & $\sigma^{\mathrm{IV}}$ & 25,8 & 23,7 & 18,5 & 33,9 & 35,2 & 38,2 & 29,2 & 44 \\
\hline
\end{tabular}

Провівши ретельний огляд прошивного стану під час його роботи, було виявлено наявність зазору між кришкою станини та самою станиною, що досягає 3-5 мм. Після дослідження напружено-деформованого стану за допомогою методу скінченних елементів, було встановлено, що місця максимальних напруг перемістились із отвору під натискний гвинт на місце реального формування тріщини (рис. 4 6). Така ситуація $є$ наслідком розвитку зазорів. Збільшення зазорів призводить до зменшення максимальних напружень в цілому по станині (рис. 7). Це пояснюється зменшенням жорсткос- ті станини і можливістю деформування 3 меншим опором. Але в цьому випадку максимальні напруження, які змістились в зону переходу плітовіни в циліндричну поверхню (рис. 6), призводять до більших коефіцієнтів інтенсивності напружень. Саме ця характеристика відповідальна за поширення тріщини. Їх збільшення обумовлено геометричним чинником, що стає несприятливим в кутовій зоні. Тому тріщина в цьому місці інтенсивніше поширюється, ніж в інших зонах. Отже, в кінцевому рахунку зазори зменшують надійність станини і 3 ними потрібно боротися. 


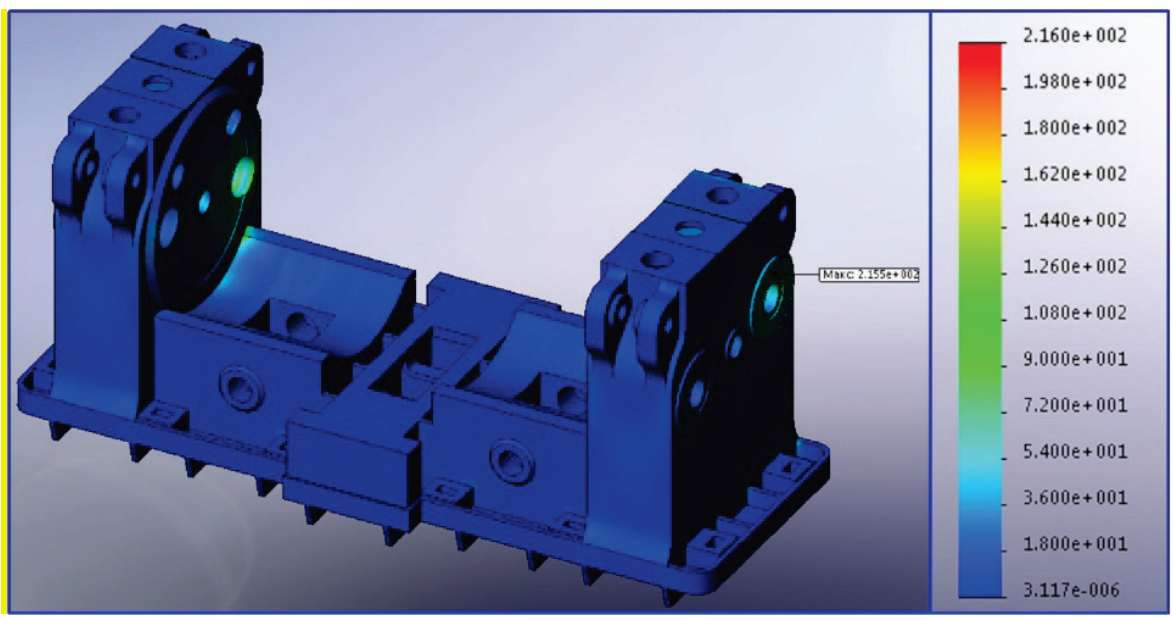

Рис. 4. Поля напружень станин прошивного стану при прокатці труби із нержавіючої сталі при правильному кріпленні кришки

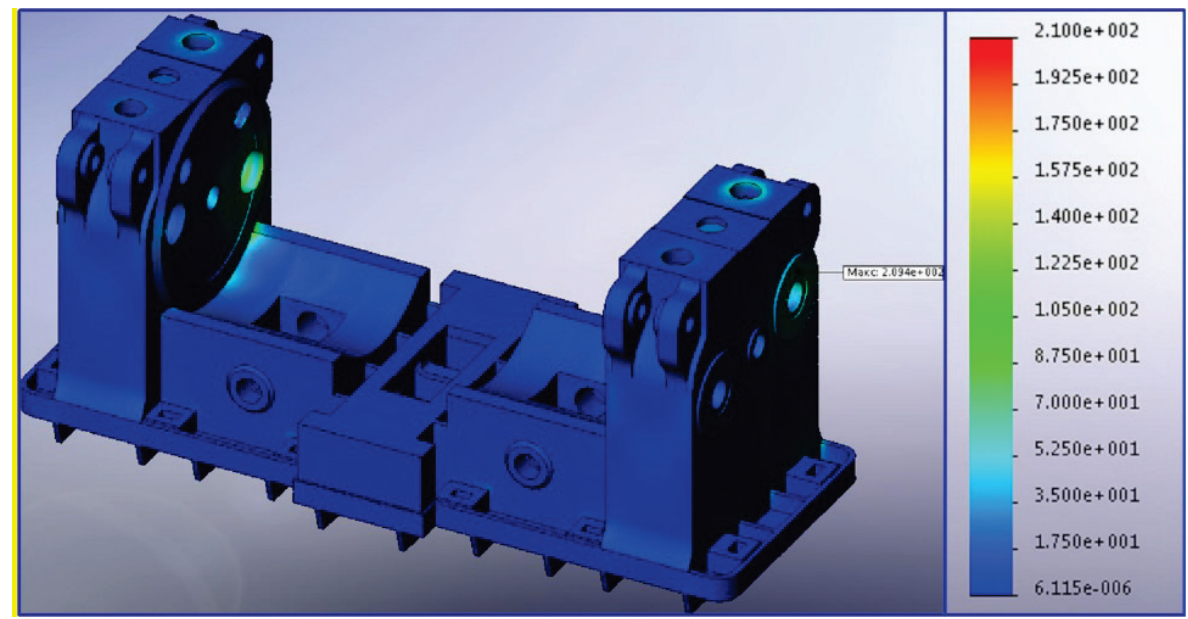

Рис. 5. Поля напружень станин прошивного стану при прокатці труби із нержавіючої сталі при зазорі між кришкою та станиною в 1 мм

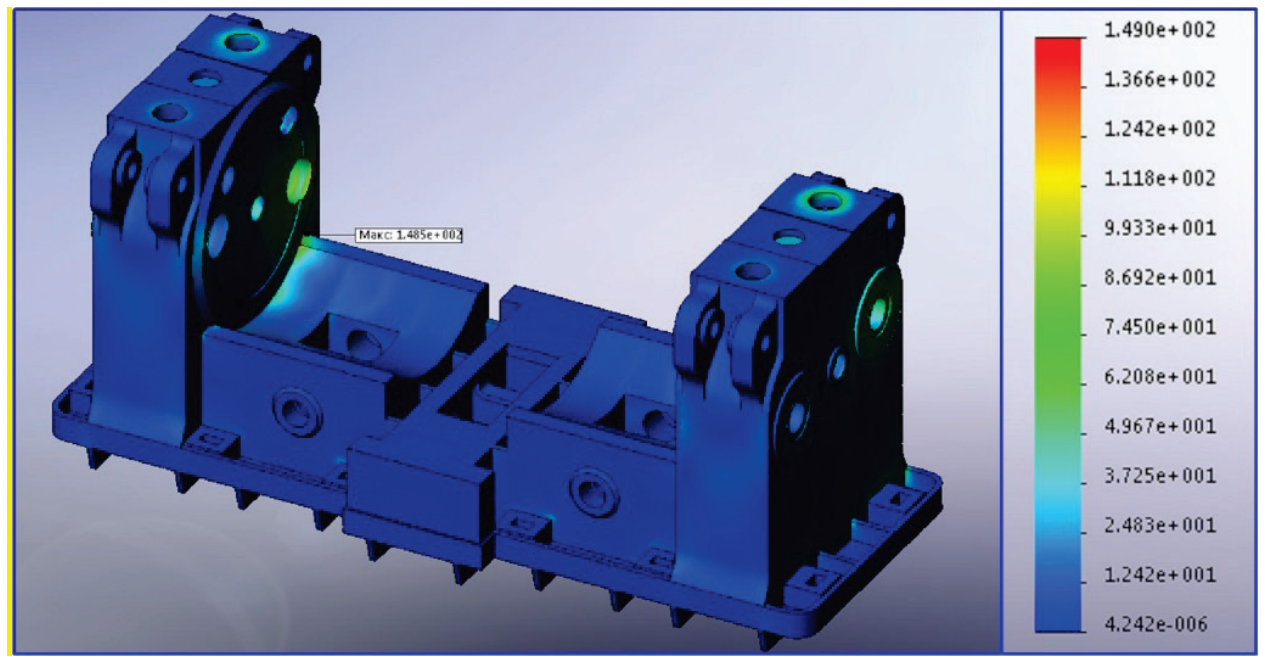

Рис. 6. Поля напружень станин прошивного стану при прокатці труби із нержавіючої сталі при зазорі між кришкою та станиною в 3 мм 


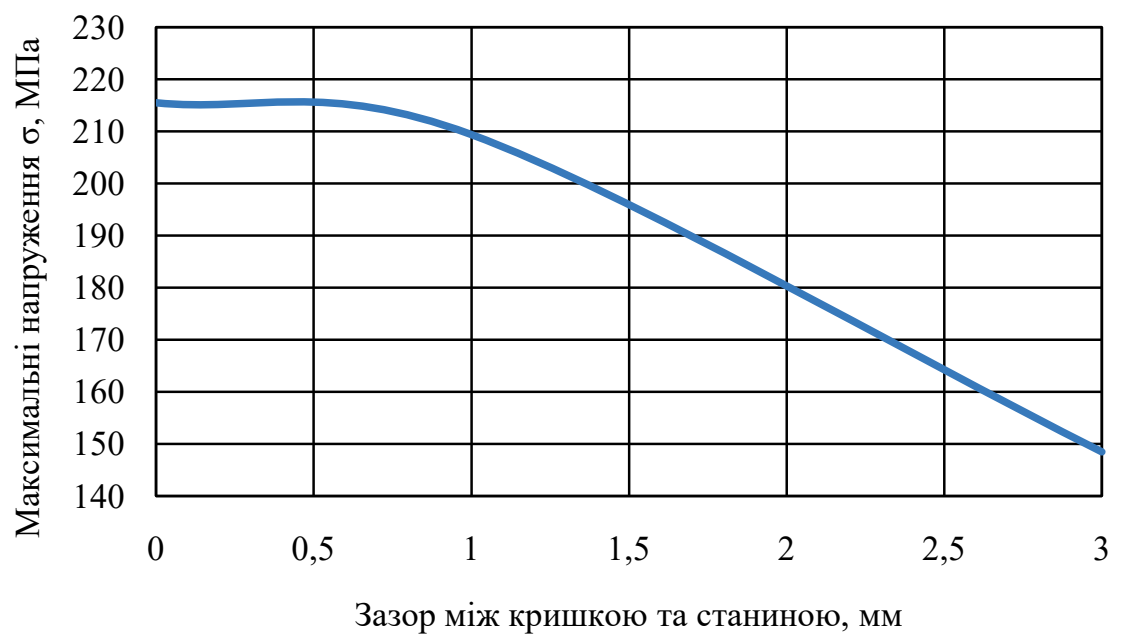

Рис. 7. Залежність максимальних напружень в станині ПС взалежності від зазору між кришкою та станиною при прокатці труби із нержавіючої сталі

Зазначені напруження вище допустимих (зазвичай для базових конструкцій допускають напруження до $120 \mathrm{MПа),} \mathrm{а} \mathrm{також} \mathrm{існує} \mathrm{небез-}$ пека вичерпання резервів міцності. Циклонавантаженість ПС при річній продуктивності ТПА 200000 тон, при середній масі однієї труби 0,7 тон, становить $2,8610{ }^{5}$ труб/рік. Якщо прийняти, що 1 цикл навантаження дорівнює 1 трубі, то за рік у станині виникає $2,860{ }^{5}$ циклів 3 максимальними значеннями напружень $\sigma_{2} \mathrm{i} \sigma_{1}$. Асиметрія циклу близька до нуля, із чого випливає, що максимальні напруження рівні подвоєним амплітудним: $\sigma{ }_{2(1)}=2 \cdot \sigma \mathrm{a}_{2(1) .}$ У зв'язку 3 вищевикладеним оцінка довговічності до появи тріщини $\mathrm{N}$ і формування функції надійності $\mathrm{P}(\mathrm{t})$ представляються вельми актуальними.

Розрахунок проводиться для дворівневого блоку з параметрами напружень $\sigma_{1}, \sigma_{2}$ i коефіці$\epsilon$ нтів $\mathrm{c}_{1}, \mathrm{c}_{2}$. Коефіцієнт варіації напружень окремих рівнів при цьому становить $\mathrm{V}_{\sigma}=0,17$.

В умовах складного напруженого стану матеріалу станини (сталь 35Л) доцільно проводити оцінку довговічності за деформаційними критеріями втоми. Треба відзначити, що для аналогічного прокатного обладнання успішно апробована деформаційна модель втоми типу [6]:

$$
\varepsilon_{a}=\frac{1}{4 N^{0,6}} \ln \frac{1}{1-\psi}+\frac{\sigma_{a R}}{E}\left(\frac{2 \cdot 10^{6}}{N}\right)^{\frac{1}{m}},
$$

де $\psi$ - коефіцієнт відносного звуження $\mathrm{aR}-$ границя витривалості на базі $20{ }^{6}$ циклів, Е модуль пружності сталі, $\mathrm{m}$ - показник нахилу кривої втоми в багатоцикловій області.
Для сталі 35Л у умовах крутіння експериментально була знайдена амплітудна границя витривалості $\tau_{-1}=104$ МПа в дотичних напруженнях [6]. Використовуючи рекомендації для розрахункового визначення характеристик опору втомі, перераховуємо границю витривалості в нормальних напруженях і одержуємо $\sigma_{\mathrm{aR}}=125 \mathrm{MПа}[4,5]$. Прийнято показник нахилу $\mathrm{m}=10$, який підтверджений експериментально для конструкційної сталі після тривалої експлуатації.

Окрихчення матеріалу, властиве металам у результаті тривалого їхнього використання, відбивається в прийнятті зниженої величини показника пластичності $\psi=0,25$ (виичайно для подібних сталей $>0,5) .3$ урахуванням вищ евикладеного, модель втоми буде:

$$
\varepsilon_{a}=0,07 N^{-0,6}+0,000625\left(\frac{2 \cdot 10^{6}}{N}\right)^{0,1} .
$$

По даній моделі одержуємо довговічність при стаціонарному навантаженні на рівні щаблів одержуємо: $\mathrm{N}_{1}=9,4 \cdot 10^{8}$ циклів, $\mathrm{N}_{2}=3,1 \cdot 10^{8}$ циклів. Для умов лінійного підсумовування пошкоджень одержуємо підсумкову довговічність при нестаціонарному режимі $\mathrm{N}_{0}=6,65 \cdot 10^{8}$ циклів.

Функція розподілу довговічності (ФРД) представляється логарифмічно нормальним законом. Средньоквадратичне відхилення (СКВ) логарифма довговічності визначається 3 урахуванням внутрішнього й зовнішнього факторів:

$$
S_{\lg N}=\sqrt{S_{a \lg N}^{2}+S_{y \lg N}^{2}} \text {. }
$$


СКВ від внутрішнього фактора ухвалюємо як максимально можливе $\mathrm{S}_{\mathrm{algN}}=0,32$. СКВ від зовнішнього фактора одержуємо як $\mathrm{S}_{\mathrm{ylgN}}=\left(\mathrm{m} \cdot \mathrm{v}_{\sigma}\right) / 2,3.3$ урахуванням цього одержуємо $\mathrm{S}_{\mathrm{lgN}}=0,78$. Остаточно ФРД має вигляд:

$$
\lg N_{P}=\left(\lg N_{0}-1,15 S_{\lg N}^{2}\right) \pm u_{P} S_{\lg N},
$$

де $\mathrm{P}$ - імовірність безвідмовної роботи, $\mathrm{u}_{\mathrm{p}}$ - нормований квантиль нормального розподілу.

Чисельна форма ФРД станини прошивного стану наступна:

$$
S_{\lg N}=8,12 \pm 0,78 u_{P} .
$$

На іiі основі одержуємо функцію надійності в графічній формі (рис. 8).
Звідси випливає, що після двох років експлуатації надійність залишається високою i становить $\mathrm{P}=0,9988$. Критичного для загального машинобудування рівня надійності $\mathrm{P}=0,98$ станина досягає через 13 років експлуатації, а надійність опускається до величини $\mathrm{P}=0,96$ після 20 років експлуатації. Якщо припустити, що станина протягом попередньої експлуатації не обслуговувалася і їі властивості не відновлювалися, то за 80 років виробіток ресурсу (накопичене пошкодження) складає $a=\left(80 \cdot 2,86 \cdot 10^{5}\right) / 10^{8,12}=0,0035$. Додатковий час експлуатації до капітального ремонту незначно збільшить пошкодження металу.

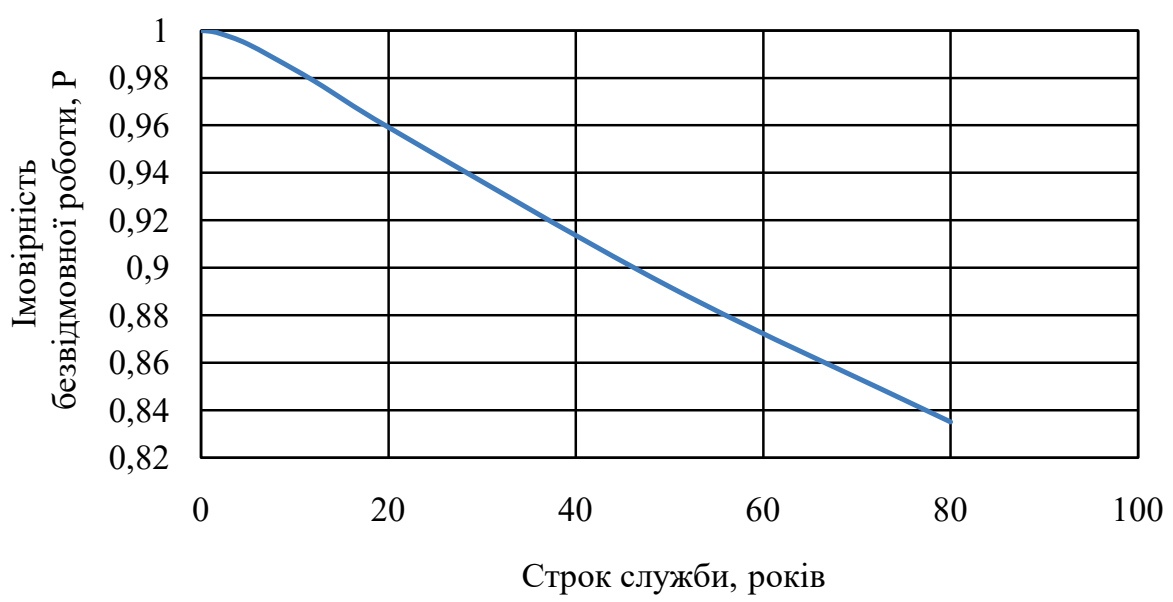

Рис. 8. Функція надійності станини прошивного стану, отримана по довговічності металу в небезпечних місцях

Найбільший інтерес представляє оцінка довговічності станини прошивного стану ТПА 350 при наявності існуючих дефектів. Для вуглецевих конструкційних сталей типу сталь 35Л граничне значення коефіцієнта інтенсивності напружень (КIH) прийняте $\mathrm{K}_{\mathrm{Ith}}=6 \mathrm{MПa} \cdot \mathrm{M}^{0,5}$. 3 часом, відбувається окрихчення матеріалу станини, що веде до зниження критичного КІН, який ухвалюємо за аналогією 3 конструкційними сталями після тривалої експлуатації $\mathrm{K}_{\mathrm{Ic}}=60$ МПам ${ }^{0,5}$. Показник ступеня рівняння Періса прийнятий $\mathrm{n}=3$. Для оцінки небезпеки дефектів використовується модель живучості, розроблена для листопрокатних валків [7].

Мінімальний радіус кругового дефекту, який може розвиватися в полі розтягувальних напружень буде:

$$
r=\frac{K_{I t h}^{2}}{1,28 \cdot \sigma^{2}} .
$$

Тоді радіус небезпечних дефектів буде $\mathrm{r}_{2}=0$, 00126 м (2 рівень) і $\mathrm{r}_{1}=0,00159$ м (1 рівень). Величина радіуса критичного дефекту $\mathrm{r}_{\mathrm{c}}$ пов'язана 3 небезпечним радіусом співвідношенням: $\mathrm{r}_{\mathrm{c}} / \mathrm{r}=\left(\mathrm{K}_{\mathrm{Ic}} / \mathrm{K}_{\mathrm{Ith}}\right)^{2}$.

Критичний радіус буде в 100 разів більше початкового: $r_{\mathrm{c} 2}=0,126 \mathrm{~m} \mathrm{i} \mathrm{r}_{\mathrm{c} 1}=0,159 \mathrm{~m}$.

Довговічність розвитку дефекту від початкового до критичного (живучість) визначається як:

$$
N_{g}=\frac{2 \cdot 10^{7} K_{I c}^{3}}{(1,28 \sigma)^{3} \pi^{1,5} \sqrt{r}}\left(1-\sqrt{\frac{r}{r_{c}}}\right) .
$$

3 цього рівняння одержуємо число циклів живучості $\mathrm{N}_{\mathrm{g} 1}=3,5 \cdot 10^{6}$ циклів (1 рівень) i $\mathrm{N}_{\mathrm{g} 1}=2,3 \cdot 10^{6}$ циклів (2 рівень). Підсумкова живучість станини стану при нестаціонарному режимі складе $\mathrm{N}_{\mathrm{g}}=3,2 \cdot 10^{6}$ циклів. 
Показник нахилу кривої живучості $-\mathrm{N}_{\mathrm{g}}$ менше, ніж для моделі втоми (більш крутий нахил діаграми) і становить $\mathrm{m}=2,27$. Тоді складова СКВ від зовнішнього фактора становить $\mathrm{S}_{\mathrm{ylgN}}=0,17$. Загальне СКВ логарифма живучості буде $\mathrm{S}_{\mathrm{lgN}}=0,36$. Функція розподілу живучості за аналогією із ФРД підкоряється логнормальному закону:

$$
\lg N_{g P}=6,35 \pm 0,36 u_{P}
$$

Для гарантованих значень довговічності в даних рівняннях слід використовувати знак мінус $(\mathrm{P}>0,5)$. Функція надійності, побудована по да- ному рівнянню, визначає живучість станини в детермінованій постановці в 7,82 року. В імовірнісній постановці, що враховує розсіювання параметрів опору руйнуванню, через 2 роки експлуатації надійність становить $\mathrm{P}=0,945$ (рис. 9).

Критичний рівень надійності $\mathrm{P}=0,98$ при живучості, що відповідає 1,42 року, а рівень надійності $\mathrm{P}=0,96$ буде досягнуто після 1,82 року експлуатації станини. Таким чином, інтенсивність вичерпання надійності функціонування станини при розвитку дефектів приблизно в 10 разів вище, ніж для початково бездефектного металу.

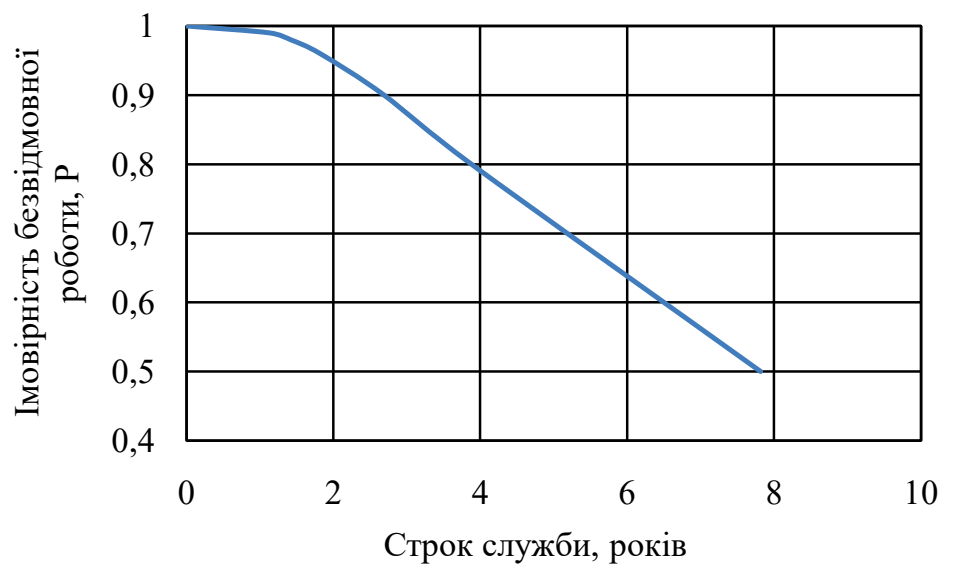

Рис. 9. Функція надійності станини прошивного стану, отримана по живучості метала в небезпечних місцях

На підставі розробленого алгоритму була продовжена оцінка надійності для більш жорстких умов експлуатації станин прошивних станів ТПА 350, які фактично склалися при роботі прошивного стану. Зміни умов експлуатації полягають в наступному: зростання продуктивності до 240000 тон на рік регламентує інтенсивність циклозмін у розмірі 343000 циклів (труб) на рік; при прокатці сплавів, що важко деформуються, максимальні напруження в станині зростають до 190 МПа, а при прокатці рядових сталей у станині виникають напруження 149 МПа. В силу цього розглядалися блоки навантаження 3 рівнем напруженостіб ${ }_{1}=149$ МПа й $\sigma_{2}=190$ МПа. При цьому варіювався параметр відносної тривалості щаблів $\mathrm{c}_{1}$ i $\mathrm{c}_{2}$. Параметр $\mathrm{c}_{2}$ характеризує частку обробки заготовок із сталей і сплавів, що важко деформуються. Для основного режиму навантаження станини прийнято $\mathrm{c}_{1}=0,8$ i $\mathrm{c}_{2}=0,2$. У якості показника надійності замість імовірності безвідмовної роботи Р використовується безрозмірний рівень ризику $\rho=(1-\mathrm{P}) / \mathrm{P}$. При $\rho=1$ ризик стає повним і експлуатація прошивного стану не припустима.

Зі збільшенням частки обробки металів, що важко деформуються, довговічність до появи тріщини знижується: до величини $\mathrm{c}_{2}=0,2$ спостерігається інтенсивне падіння ресурсу в 2,7 рази ( при $\mathrm{c}_{2}=0$ режим навантаження стаціонарний із напруженням $\sigma_{1}$ ), після чого спостерігається плавний спад графіка ( ресурс знижується в 2 рази при $c_{2}=0,5$ у порівнянні 3 основним режимом (рис. 10)).

Результати розрахунків надійності в більш жорстких умовах експлуатації представлені на рис. 11-13. 3 них випливає, що строк безпечної експлуатації минув через 73 - 75 років від іiї початку. 


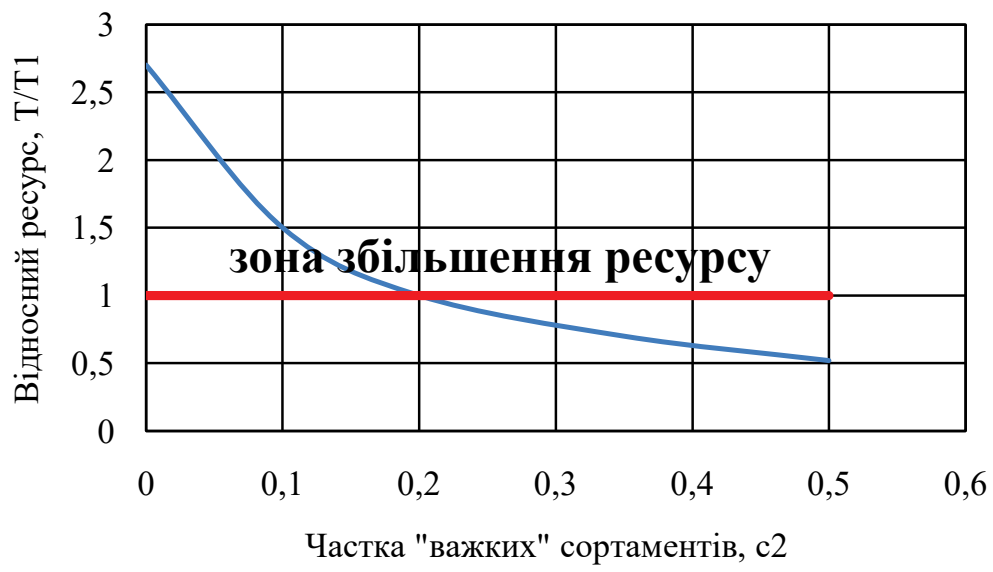

Рис. 10. Вплив частки прокатки металів, що важко деформуються (параметра блоку $\mathrm{c}_{2}$ ) на відносний термін служби станини прошивного стану $\mathrm{T} / \mathrm{T}_{1}$, де $\mathrm{T}_{1}$ - термін служби при $\mathrm{c}_{2}=0,2$

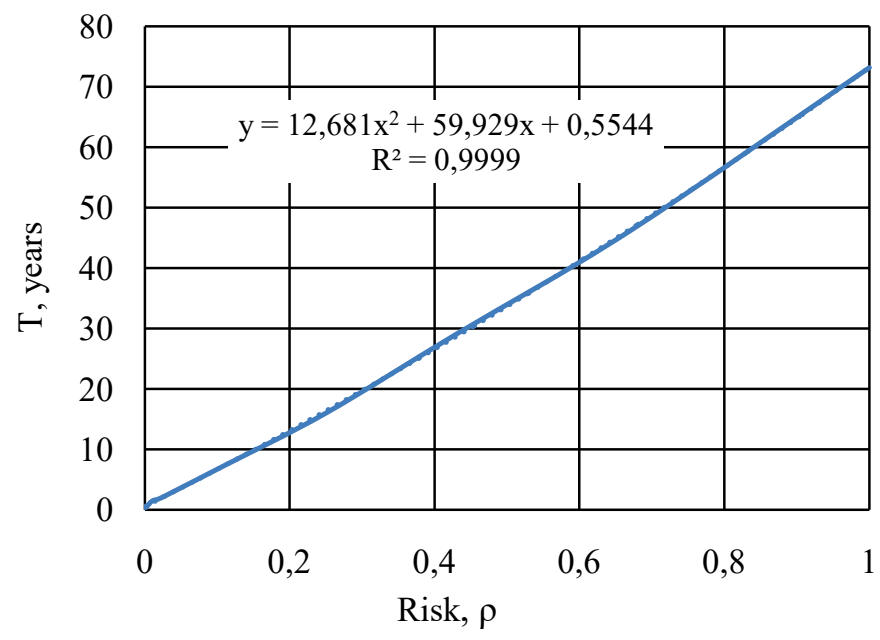

Рис. 11. Функція розподілу терміну служби станини прошивного стану ТПА 350 за рівнем ризику, отримана при двоступінчастому основному блоці навантаження

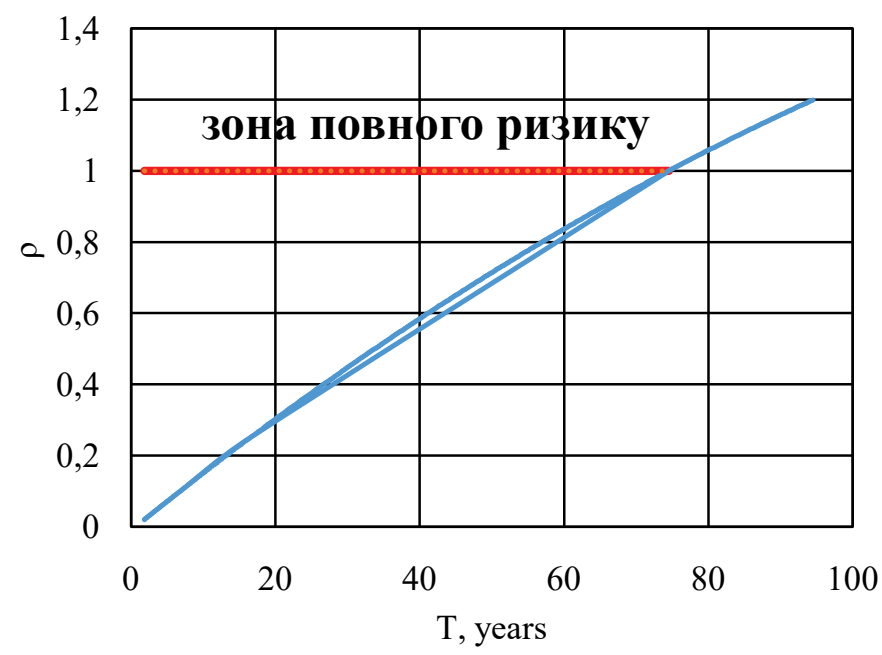

Рис. 12. Функція ризику станини прошивного стану ТПА 350, отримана при об'єднанні втомних пошкоджень двох небезпечних місць 


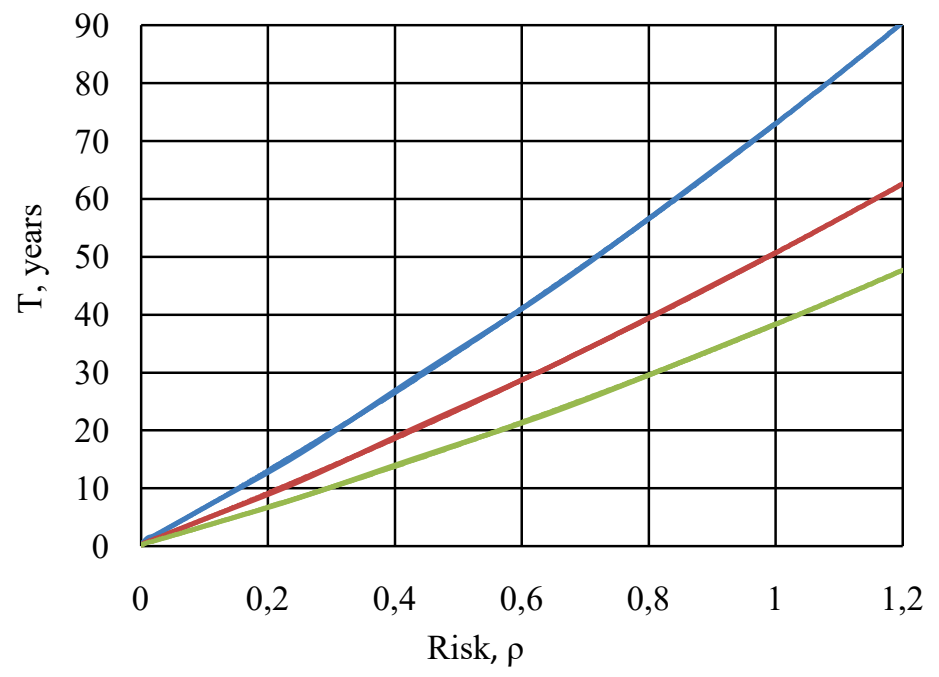

Рис. 13. Функція розподілу терміну служби станини прошивного стану ТПА 350 за рівнем ризику, отримана при двоступінчастих блоках навантаження 3 відносними тривалостями $\mathrm{c}_{2}=0,2$ (верхня крива), $\mathrm{c}_{2}=0,35$ (середня крива), $\mathrm{c}_{2}=0,5$ (нижня крива)

При збільшенні частки обробки сталей, що важко деформуються, безпечна експлуатація минула б через 50 років $\left(\mathrm{c}_{2}=0,35\right)$ або через 38 років $\left(\mathrm{c}_{2}=0,5\right)$ (рис. 14$)$.

При основному режимі навантаження станини ПС знижується розмір радіуса сферичного дефекту, який може збільшуватися. Він становить $\mathrm{r}_{2}=0,00077 \mathrm{~m}$. Сторазове збільшення дефекту відбувається за період живучості $\mathrm{N}_{1}=2,84 \cdot 10^{6}$ циклів і $\mathrm{N}_{2}=1,7 \cdot 10^{6}$ циклів. Отримані на цій підставі функції розподілу живучості і ризику (рис. 14 і 15) показують, що за за- пропонованим критерієм ризик руйнування наступає через 5,2 року експлуатації.

Для продовження експлуатації станини ПС пропонується: надійно закріпити верхню кришку станини прошивного стану (рис. 16), тому що зазори в місці з'єднання сприяють росту локальних напружень, наслідки появи яких і аналізувалися в даній роботі; максимально знизити (виключити) кількість труб, що виготовляються, із металів, що важко деформуються; робити діагностування кліті, перевіряти розміри тріщин не рідше ніж, через $2-3$ місяця.

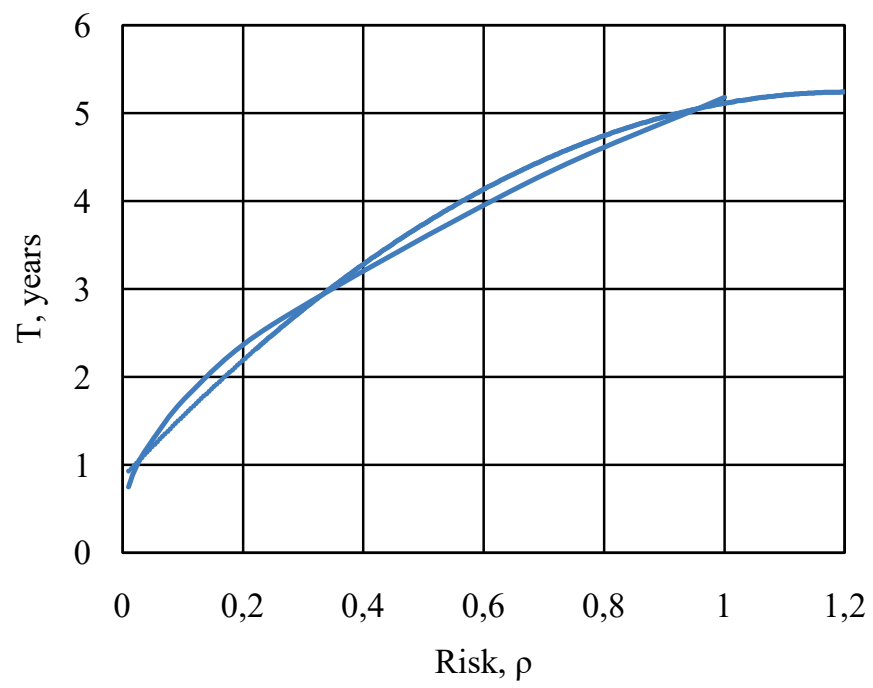

Рис. 14. Функція розподілу живучості за рівнем ризику при рості сферичного дефекту в станині прошивного стану ТПА 350 під дією основного блоку навантаження 


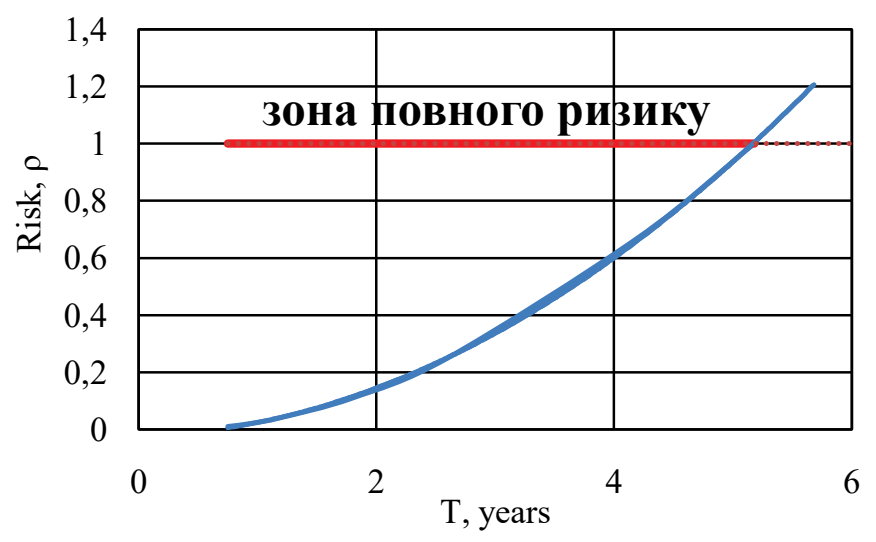

Рис. 15. Функція ризику при рості сферичного дефекту в станині прошивного стану ТПА 350 під дією основного блоку навантаження
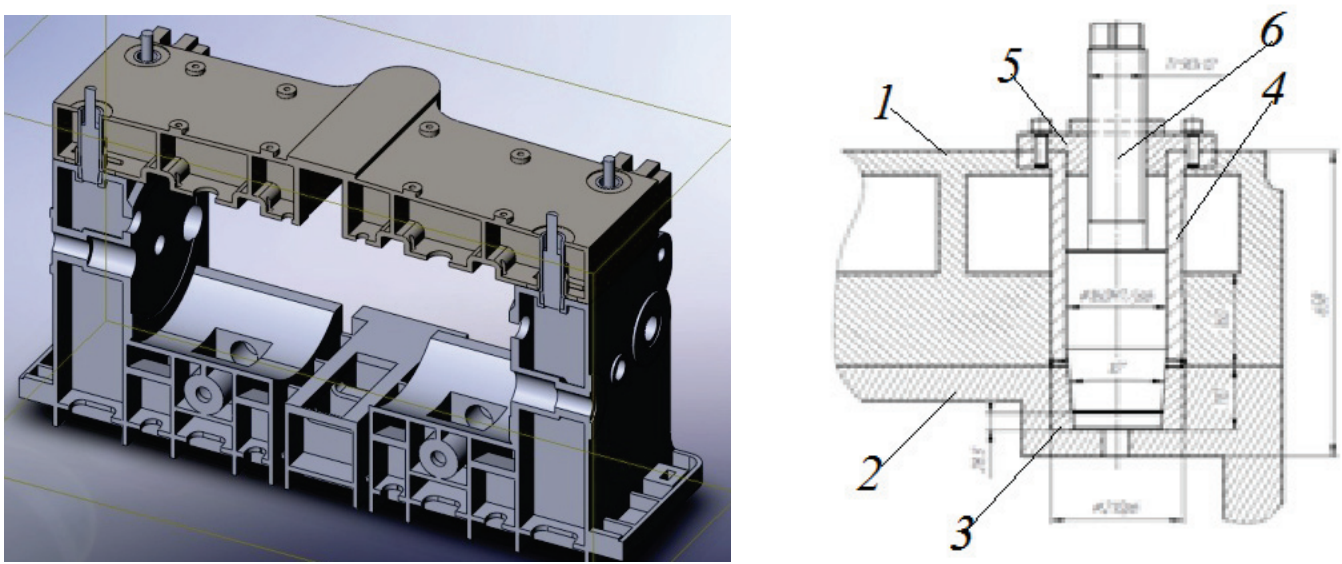

Рис. 16. Робоча кліть прошивного стану ТПА 350 із гвинтовим механізмом фіксації кришки: 1 - кришка; 2 - станина; 3 - склянка; 4 - гільза; 5 - фланець; 6 - гвинт регулювальний

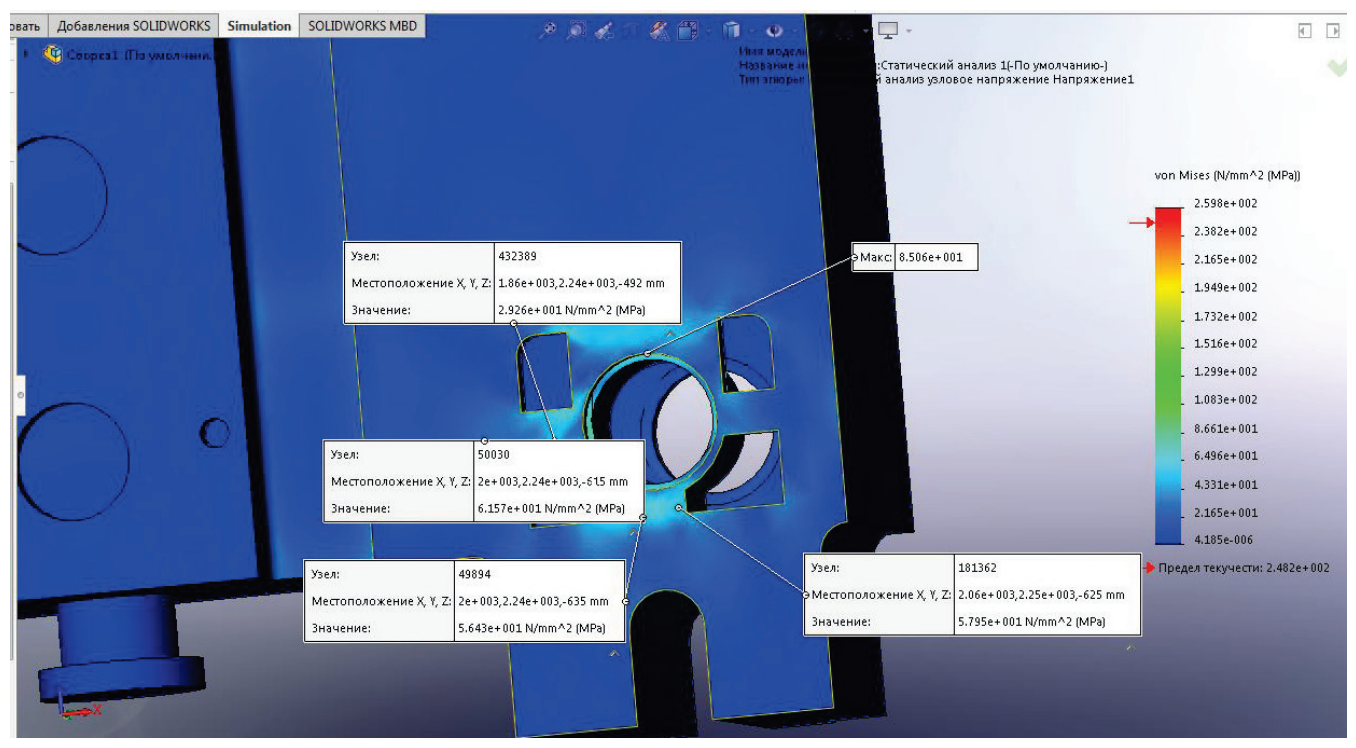

a)

б)

Рис. 17. Напружено-деформований стан станини а) і кришки б) робочої кліті прошивного стану ТПА 350 з урахуванням гвинтового механізму фіксації кришки 
Дослідження напружено-деформованого стану станини і кришки робочої кліті прошивного стану ТПА 350 (рис. 17) показує, що фіксація кришки в місцях їх надійного закріплення сприяє зниженню локальних напружень при виготовленні труб із металів, що важко деформуються. Максимальні напруження в місцях їх локалізації відповідно становлять: на станині 140 МПа (рис. 17 а), а на кришці приблизно 109 МПа (рис. 17 б).

\section{Висновки}

1. Небезпеку становлять дефекти, які з'являються в напружених зонах. Їхні початкові розміри малі для надійного діагностування. Але їх критичні розміри досить великі, щоб їх не виявити при обстеженнях.

2. Безпека станини при умовах експлуатації зі збільшенням жорсткості, фактично спостережуваних у реальності, була вичерпана після 75 років експлуатації. У даний момент станина прошивного стану працює в зоні повного ризику, супроводжуваного утворенням тріщин.

3. Період живучості сферичного дефекту становить близько 5 років. Після цього дефект трансформується в тріщину з погано визначною геометрією і розвивається по закономірностях, що вимагають окремого вивчення. Найбільш ефективно в цьому плані здійснювати ії контроль відомими діагностичними методами.

4. Встановлено, що шляхом надійного закріплення кришки станини прошивного стану знижуються напруження при виготовленні труб зі сплавів, що важко деформуються,так як досягається локалізація напружень у зоні їх концентрації. У зв'язку із цим запропоновано максимально знизити (виключити) кількість труб, що виготовляються із металів, що важко деформуються; робити діагностування робочої кліті ПС ТПА 350, перевіряти розміри тріщин не рідше, ніж через $2-3$ місяця.

\section{Бібліографічний перелік}

1. Коликов А. П., Романенко В. П., Самусев С. В., Шейх-Али А. Д., Фролочкин В. В. Машины и агрегаты трубного производства: учебное пособие для вузов. М. : МИСиС, 1998. 536 с.

2. Галлагер Р. Метод конечных элементов. Основы : пер с англ. М. : Мир, 1984. 428 с.

3. Алямовский А. А. Инженерные расчёты в SolidWorksSimulation. М. : БМК Пресс, 2010. $464 \mathrm{c}$.
4. Гребеник В. М., Цапко В. К. Надёжность металлургического оборудования: справочник. М. : Металлургия, 1980. 343 с.

5. Рахманов С. Р., Белодеденко С. В., Поворотний В. В., Вышинский В. Т. Оценка надежности станины рабочей клети автоматического стана ТПА 350 после длительной эксплуатации. Черная металлургия. Бюллетень научнотехнической и экономической информации. 2020. T. 76. № 1. C. 59-67. DOI: 10.32339/01355910-2020-1-59-67.

6. Трощенко В. Т., Сосновский Л. А. Сопротивление усталости металлов и сплавов: справочник. Ч.1. Киев : Наукова думка, 1987. 511 с.

7. Белодеденко С. В., Угрюмов Д. Ю. Эффективность прогнозирования ресурса элементов прокатного оборудования и деформационные критерии усталости. Металлургическая и горнорудная промышленность. 2003. № 5. C. 86-90.

8. Белодеденко С. В., Яцуба А. В., Клименко Ю. М. Оценка технического состояния и прогнозирование живучести прокатных валков. Металлургическая и горнорудная промышленность. 2015. № 3. С. 87-94.

\section{References}

1. Kolikov A. P., Romanenko V. P., Samusev S. V., Sheikh-Ali A. D., Frolochkin V. V. (1998). Mashiny i agregaty trubnogo proizvodstva. Moskva: MISIS

2. Gallager R. (1984). Metod konechnykh ehlementov. Osnovy. Moskva: Mir

3. Aliamovskii A. A. (2010). Inzhenernye raschety $v$ SolidWorksSimulation. Moskva: BMK Press

4. Grebenik V. M., Tsapko V. K. (1980). Nadezhnost metallurgicheskogo oborudovaniia: spravochnik. Moskva: Metallurgiia

5. Rakhmanov S. R., Belodedenko S. V., Povorotnii V. V., Vyshinskii V. T. (2020). Otsenka nadezhnosti staniny rabochei kleti avtomaticheskogo stana TPA 350 posle dlitelnoi ehkspluatatsii. Chernaia metallurgiia. Biulleten nauchnotekhnicheskoi $i$ ehkonomicheskoi informatsii, 76 (1), 59-67. https://doi.org/10.32339/0135-59102020-1-59-67

6. Troshchenko V. T., Sosnovskii L. A. (1987). Soprotivlenie ustalosti metallov i splavov. Chast 1. Kiev : Naukova dumka

7. Belodedenko S. V., Ugriumov D. IU. (2003). Ehffektivnost prognozirovaniia resursa eh- 
lementov prokatnogo oborudovaniia i deformatsionnye kriterii ustalosti. Metallurgicheskaia $i$ gornorudnaia promyshlennost, (5), 86-90

8. Belodedenko S. V., Iatsuba A. V., Klimenko
IU. M. (2015). Otsenka tekhnicheskogo sostoianiia i prognozirovanie zhivuchesti prokatnykh valkov. Metallurgicheskaia $i$ gornorudnaia promyshlennost, (3), 87-94

Рахманов Сулейман Рахманович, НВП «Восток Плюс» (м. Дніпро, Україна). E-mail: npfvostokplus@gmail.com

Білодіденко Сергій Валентинович, професор, доктор технічних наук, завідувач кафедри машин і агрегатів металургійного виробництва, Національна металургійна академія України (Дніпро, Україна). ORCID ID: 0000-0002-5768-594X. E-mail: sergeibelo@gmail.com

Гануш Василь Іванович, старший викладач, кафедра машин і агрегатів металургійного виробництва, Національна металургійна академія України (Дніпро, Україна). E-mail: HanushVasiliy@gmail.com

Хацкелян Ігор Павлович, Інтерпайп Україна (м. Дніпро, Україна). E-mail: npfvostokplus@gmail.com

Поворотний Віктор Володимирович, НВП «Восток Плюс» (м. Дніпро, Україна). E-mail: vicktorpovar@gmail.com

\section{ЗАБЕЗПЕЧЕННЯ НАДІЙНОСТІ СТАНИНИ РОБОЧОЇ КЛІТІ ПРОШИВНОГО СТАНУ ТПА 350 ПІСЛЯ ЇЇ ДОВГОТРИВАЛОЇ ЕКСПЛУАТАЦІї}

Мета. Дослідження напружено-деформованого стану станини робочої кліті прошивного стану трубопрокатного агрегату 350 (ТПА 350). Розробка методики визначення надійності станини робочої кліті прошивного стану ТПА 350 після їі довготривалої експлуатації. Розробка стратегії подальшої експлуатації прошивного стану ТПА 350.

Методика. При виконанні роботи проводилися тензометрічні виміри напружень, що виникають у станині прошивних станів ТПА 350, проводилися дослідження 3D моделі станини. Було розроблено математичні моделі для визначення функції розподілу довговічності станини прошивного стану та показника безпеки, а також для визначення довговічності станини при наявності існуючих дефектів.

Результати. Наведено результати досліджень 3D моделі станин прошивного стану TПА 350. Визначено напружено-деформований стан робочої кліті прошивного стану ТПА 350. Встановлено, що в станиніробочої кліті прошивного стану виникають максимальні напруження в зонах виявлених раніше тріщин, місця концентрації максимальних напружень «мігрують» при зміні умов закріплення станіни. Виявлено, що небезпеку представляють дефекти (тріщини), які з'являються в напружених зонах станини робочої кліті. Виявлено, що початкові розміри дефектів малі для надійного діагностування, але їх критичні розміри достатньо великі, щоб їх не виявити при обстеженнях. Встановлено, що безпека станини прошивного стану при більш жорстких умовах експлуатації, які фактично спостерігаються у реальності, була вичерпана після 75 років експлуатації. Дослідженнями напруженодеформованого стану встановлено, що зазори в місці з'єднання кришки й станини робочої кліті сприяють росту локальних напружень, наслідки появи яких аналізувалися в даній роботі.

Наукова новизна. Вперше проведено дослідження надійності станини прошивного стану ТПА 350 після 80 років експлуатації. При розробці математичної моделі опору втомному руйнуванню використано I та II моди руйнування.

Практична цінність. Розрахунки показують, що в даний момент станина прошивного стану працює в зоні повного ризику, що супроводжується утворенням тріщин. Період живучості сферичного дефекту становить близько 5 років, після цього дефект трансформується в тріщину 3 погано визначною геометрією й розвивається по закономірностях, що вимагають окремого вивчення. Показано, що найбільш ефективно в цьому плані здійснювати їі контроль неруйнуючими діагностичними методами. Для продовження експлуатації станини прошивного стану пропонується: надійно закріпити верхню кришку станини прошивного стану гвинтовим механізмом фіксації. Запропоновано максимально знизити (виключити) кількість труб, що виготовляються, із сплавів, що важко деформуються, робити діагностування кліті й регулярно перевіряти розміри тріщин. 
Ключові слова: трубопрокатний агрегат, прошивний стан, станина, кришка, напруженодеформований стан, поля напружень, тріщина, дефекти, надійність, довговічність, живучість.

Suleiman Rakhmanov, "Vostok Plus" (Dnipro, Ukraine). E-mail: npfvostokplus@gmail.com

Sergey Belodedenko, Professor, Doctor of Technical Sciences, Manager of the department of metallurgical production machines and units, National Metallurgical Academy of Ukraine (Dnipro, Ukraine). ORCID ID: 0000-0002-5768-594X. E-mail: sergeibelo@gmail.com

Vasiliy Hanush, Senior teacher, Department of Metallurgical Production Machines and Units, National Metallurgical Academy of Ukraine (Dnipro, Ukraine). E-mail: HanushVasiliy@gmail.com

Ihor Khatskelian, Interpipe Ukraine (Dnipro, Ukraine). E-mail: npfvostokplus@gmail.com

Viktor Povorotniy, "Vostok Plus" (Dnipro, Ukraine). E-mail: vicktorpovar@gmail.com

\section{ESSURING OF THE WORKING STAND FRAME RELIABILITY OF THE PIERCING MILL 350 FOR ROLLING PIPES AFTER ITS LONG TERM OPERATION}

Purpose. Investigation of the stress-strain state of the frame of the working stand of the piercing mill of the pipe rolling unit 350. Development of a method for determining the reliability of the frame of the working stand of the piercing state pipe rolling unit 350 after its long-term operation. Development of a strategy for further operation of the pipe rolling unit 350 piercing mill.

Methods. The tensometric measurements of the stresses arising in the frame of pipe rolling unit 350 piercing mills were carried out; studies of the 3D model of the frame were carried out. Mathematical models have been developed to determine the function of the distribution of the durability of the frame of the piercing mill and the safety index, as well as to determine the durability of the frame in the presence of existing defects.

Results. The results of the 3D model research of the piercing mill of pipe rolling mill 350 are presented. The stress-strain state of the working stand of the piercing millof pipe rolling mill350 is determined. It is established that maximum stresses occur in zones of the working stand of the piercing mill in the zones of previously detected cracks, places of concentration of maximum stresses "migrate" when changing the conditions of fixing of the frame.Defects (cracks) occurring in the stressed areas of the working standare found to be dangerous. Initial defect sizes were found to be small for reliable diagnosis, but their critical dimensions were large enough to not be detected in the examinations. It has been established that the safety of the piercing millunder the tougher operating conditions actually observed in reality has been exhausted after 75 years of operation. Studies of stress-strain state found that the gaps at the junction of the cover and the frame of the workingstand contribute to the growth of local stresses, the consequences of which were analyzed in this work.

Originality. For the first time the research of reliability of the frame of a piercing condition of pipe rolling mill 350 after 80 years of operation is carried out. In developing a mathematical model of resistance to fatigue failure, I and II modes of destruction were used.

Practical implications. The calculations show that at the moment the workingstand of the piercing millis operating in the zone of complete risk, which is accompanied by the formation of cracks. The survivability period of a spherical defect is about 5 years, after which the defect is transformed into a crack with badly defined geometry and develops according to regularities that require separate study. It is shown that the most effective in this regard is to control it with non-destructive diagnostic methods. To continue the operation of the piercing mill it is proposed to securely fasten the upper cover of the piercing millwith a screw fixing mechanism. It is suggested to minimize (exclude) the number of tubes being manufactured from deformed alloys, to diagnose stands and to regularly check the size of cracks.

Key words: pipe rolling mill, piercing mill, frame, cover, stress-strainstate, tensions' fields, crack, defects, reliability, durability, survivability.

Рахманов Сулейман Рахманович, НПП «Восток Плюс» (г. Днепр, Украина). Е-mail: npfvostokplus@gmail.com

Белодеденко Сергей Валентинович, профессор, доктор технических наук, заведующий кафедрой машин и агрегатов металлургического производства, Национальная металлургическая академия 
Украины (г. Днепр, Украина). ORCID ID: 0000-0002-5768-594X. E-mail: sergeibelo@gmail.com

Гануш Василий Иванович, старший преподаватель, кафедра машин и агрегатов металлургического производства, Национальная металлургическая академия Украины (г. Днепр, Украина). E-mail: HanushVasiliy@gmail.com

Хацкелян Игорь Павлович, Интерпайп Украина (г. Днепр, Украина). E-mail: npfvostokplus@gmail.com

Поворотний Виктор Владимирович, НПП «Восток Плюс» (г. Днепр, Украина). E-mail: vicktorpovar@gmail.com

\section{ОБЕСПЕЧЕНИЕ НАДЕЖНОСТИ СТАНИНЫ РАБОЧЕЙ КЛЕТИ ПРОШИВНОГО СТАНА ТПА 350 ПОСЛЕ ЕЕ ДОЛГОВРЕМЕННОЙ ЭКСПЛУАТАЦИИ}

Цель. Исследование напряженно-деформированного состояния станины рабочей клети прошивного стана трубопрокатного агрегата 350 (ТПА 350). Разработка методики определения надежности станины рабочей клети прошивного стана ТПА 350 после ее длительной эксплуатации. Разработка стратегии дальнейшей эксплуатации прошивного стана ТПА 350.

Методика. При выполнении работы проводились тензометрические измерения напряжений, возникающих в станине прошивных станов ТПА 350, проводились исследования 3D модели станины. Были разработаны математические модели для определения функции распределения долговечности станины прошивного стана и показателя безопасности, а также для определения долговечности станины при наличии существующих дефектов.

Результаты. Приведены результаты исследований 3D модели станин прошивного стана ТПА 350. Определено напряженно-деформированное состояние рабочей клети прошивного стана ТПА 350. Установлено, что в станине рабочей клети прошивного стана возникают максимальные напряжения в зонах выявленных ранее трещин, места концентрации максимальных напряжений «мигрируют» при изменении условий закрепление станины. Выявлено, что опасность представляют дефекты (трещины), которые появляются в напряженных зонах станины рабочей клети. Выявлено, что начальные размеры дефектов малы для надежного диагностирования, но их критические размеры достаточно велики, чтобы их обнаружить при обследованиях. Установлено, что безопасность станины прошивного стана при более жестких условиях эксплуатации, которые фактически наблюдаются в реальности, была исчерпана после 75 лет эксплуатации. Исследованиями напряженно-деформированного состояния установлено, что зазоры в месте соединения крышки и станины рабочей клети способствуют росту локальных напряжений, последствия появления которых анализировались в данной работе.

Научная новизна. Впервые проведено исследование надежности станины прошивного стана ТПА 350 после 80 лет эксплуатации. При разработке математической модели сопротивления усталостному разрушению использованы I и II моды разрушения.

Практическая ценность. Расчеты показывают, что в данный момент станина прошивного стана работает в зоне полного риска, сопровождаемого образованием трещин. Период живучести сферического дефекта составляет около 5 лет, после этого дефект трансформируется в трещину с плохо определяемой геометрией и развивается по закономерностям, требующим отдельного изучения. Показано, что наиболее эффективно в этом плане осуществлять ее контроль неразрушающими диагностическими методами. Для продолжения эксплуатации станины прошивного стана предлагается: надежно закрепить верхнюю крышку станины прошивного стана винтовым механизмом фиксации. Предложено максимально снизить (исключить) количество труб, изготавливаемых из сплавов, труднодеформируемых, делать диагностирования клети и регулярно проверять размеры трещин.

Ключевые слова: трубопрокатный агрегат, прошивной стан, станина, крышка, напряженнодеформированное состояние, поля напряжений, трещина, дефекты, надежность, долговечность, живучесть. 